\title{
P04-8-11 Poster session
}

\section{Centella asiatica (L.) Urban extract administration prevent macrophage polarization towards M1 macrophage on the kidney of diabetic nephropathy rat model}

\author{
Dwi Aris Agung Nugrahaningsih ${ }^{1}$, Sadli Syarifuddin², Amalia Anita Hawas², Eti \\ Nurwening Sholikhah ${ }^{1}$, Ngatidjan Ngatidjan ${ }^{1}$ \\ ${ }^{1}$ Pharmacology \& Therapy Department, Faculty of Medicine Universitas Gadjah Mada, Indonesia, ${ }^{2}$ Postgraduate \\ Program of Basic Medical Science and Biomedical, Medical Faculty, Universitas Gadjah Mada, Indonesia
}

Background: Diabetic nephropathy (DN) is one of the most devastating complications of diabetes mellitus (DM). Diabetic nephropathy development in diabetes is related with machrophage polarization towards M1 macrophage. Centella asiatica (L.) Urban (C. asiatica) is one of herbs used for nephron-protective agent. It is known to inhibit the activity of Angiotensine Coverting Enzyme (ACE).

Objective: To investigate the effect of $\mathrm{C}$. asiatica extract on kidney macrophage polarization of diabetic nephropathy rat model.

Method: Rat was treated with Streptozotocin-Nicotinamide to develop type 2 Diabetes Mellitus (DM). The diabetic nephropathy developed 8 weeks after type $2 \mathrm{DM}$ developed. The rats were divided into 6 groups of treatment which are non DM, DM without treatment, DM with captopril, DM with C. asiatica extract $250 \mathrm{mg} / \mathrm{kg} \mathrm{BW} /$ day, DM with C. asiatica extract $500 \mathrm{mg} / \mathrm{kg} \mathrm{BW} /$ day and DM with C. asiatica extract $1000 \mathrm{mg} / \mathrm{kgBW} /$ day. Treatment was given for 8 weeks. In the end of the treatment, the rats were put in metabolic cage for urin collection. Blood samples were taken to measure urea serum level. Rats were sacrificed and the kidney was collected for histological examination and M1 and M2 machrophage marker mRNA expression measurement were lower in

Results: Urin protein, serum ureum level and glomerulosclerosis score were lower in C. asiatica extract treated group compare to those on DM without treatment group $(p<0.05)$. The highest M1 macrophage mRNA marker was in DM group. Meanwhile the lowest M2 macrophage mRNA marker was in DM group. The M1/M2 macrophage mRNA marker ratio C. asiatica extract treated group compare to those on DM without treatment group $(\mathrm{p}<0.05)$.

Conclusions: C. asiatica extract prevent macrophage polarization towards M1 on rat model of diabetic nephropathy. 